\title{
Mole per Kilogram
}

National Cancer Institute

\section{Source}

National Cancer Institute. Mole per Kilogram. NCI Thesaurus. Code C68740.

A unit amount of substance content (molality unit) defined as one mole of solute per one kilogram of solvent. 